\title{
PENGARUH VARIETAS DAN TIPE STARTER TERHADAP KADAR AIR, KADAR PROTEIN KASAR, DAN KADAR SERAT KASAR PADA SILASE TEBON JAGUNG
}

\author{
The Effect of Different Variety and Type of Starter on Moisture, Crude Protein, and Crude Fiber Content \\ of Corn Forage Silage
}

Susan Dian Mirsani, Rudy Sutrisna, Agung Kusuma Wijaya, Liman

Departement of Animal Husbandry, Faculty of Agriculture, University of Lampung Jl. Prof. Dr. Soemantri Brojonegoro No.1 Gedong Meneng Bandar Lampung 35145

e-mail : dianmirsani@gmail.com

\begin{abstract}
This study aimed to investigate the effect of different varieties and type of starter on moisture, crude protein, and crude fibre of corn forage silage. This research was conducted in May - August 2019 at the Laboratory of Nutrition and Animal Feed, Department of Animal Husbandry, Faculty of Agriculture, University of Lampung. The experimental design used was a factorial Complete Randomized Design (CRD) with 3 replications. The factors studied were (1) corn forage varieties, which consisted of two varieties, namely BISI-18 and NK-212 and (2) type of starter, which consisted of two types, namely molasses and bran. The results showed that there was no interaction $(\mathrm{P}>0.05)$ between variety of corn forages and type of starter on moisture content, crude protein, and crude fiber content. The use of different corn forage varieties had no significant effect $(\mathrm{P}>0.05)$ on moisture content, crude protein, and crude fiber content. The use of different types of starter had no significant effect $(\mathrm{P}>0.05)$ on moisture content, crude protein, and crude fiber content.
\end{abstract}

Keywords: Crude fibre, Crude protein, Moisture content, Starter, Varieties

\begin{abstract}
ABSTRAK
Penelitian ini bertujuan untuk mengetahui kadar air, protein kasar, dan serat kasar silase tebon jagung dengan varietas berbeda (BISI-18, NK-212) yang diberikan berbagai jenis starter (molases, dedak). Penelitian ini dilaksanakan pada Mei--Agustus 2019 di Laboratorium Nutrisi dan Makanan Ternak, Jurusan Peternakan, Fakultas Pertanian, Universitas Lampung. Rancangan percobaan yang digunakan adalah Rancangan Acak Lengkap (RAL) faktorial dengan 3 kali ulangan. Faktor yang diteliti adalah (1) varietas hijauan jagung, yang terdiri dari dua varietas yaitu BISI-18 dan NK-212 dan (2) starter, yang terdiri dari dua jenis yaitu molases dan dedak. Hasil penelitian menunjukkan bahwa tidak ada interaksi $(\mathrm{P}>0,05)$ antara penggunaan jenis hijauan dan bahan aditif terhadap kadar air, protein kasar, dan serat kasar. Penggunaan varietas hijauan yang berbeda tidak berpengaruh nyata $(\mathrm{P}>0,05)$ terhadap kadar air, protein kasar, dan serat kasar. Penggunaan jenis starter yang berbeda tidak berpengaruh nyata $(\mathrm{P}>0,05)$ terhadap kadar air, protein kasar dan serat kasar.
\end{abstract}

Kata kunci: Kadar air, Protein kasar, Serat kasar, Starter, Varietas

\section{PENDAHULUAN}

Hijauan pakan ternak merupakan sumber nutrisi utama pada ternak ruminansia. Salah satu hijauan pakan ternak yang ketersediaannya melimpah di Indonesia yaitu tebon jagung. Bagian dari tanaman jagung yang dapat dimanfaatkan sebagai hijauan pakan ternak yaitu batang, daun, dan buah jagung muda. Tanaman jagung yang banyak ditanam di Indonesia memiliki beberapa varietas. Oleh sebab itu, perlu dilakukan pemilihan varietas jagung yang tepat untuk dapat dimanfaatkan sebagai hijauan makanan ternak. Pemilihan varietas tanaman jagung untuk pakan ternak bertujuan untuk memperoleh hijauan pakan dengan kualitas terbaik.

Tebon jagung digunakan sebagai pakan ternak karena produksinya tinggi dalam waktu yang singkat dan mempunyai nilai nutrisi yang baik. Berdasarkan penelitian yang dilakukan Fitri (2015) tebon jagung memiliki kandungan 
bahan kering sebesar 92,1\%, protein kasar sebesar 9,9\%, serat kasar sebesar 29,6\%, dan lemak kasar sebesar 1,9\%. Saat musim hujan, ketersediaan hijauan melimpah, tetapi terbuang karena mengalami pembusukan. Saat musim kemarau ketersediaan hijauan berkurang, sehingga menjadi masalah karena ternak kekurangan pakan. Dibutuhkan teknologi pengolahan pakan yang dapat mengawetkan hijauan pakan pada musim hujan dan dapat digunakan pada musim kemarau. Usaha yang tepat untuk melakukan pengawetan hijaun pakan adalah dengan metode silase. Silase adalah hasil fermentasi dari bahan pakan yang berkadar air tinggi, dalam keadaan kedap udara (anaerob) oleh bakteri asam laktat (Subekti et al., 2013).

Prinsip pembuatan silase adalah fermentasi hijauan oleh mikroba yang banyak menghasilkan asam laktat. Mikroba yang paling dominan adalah dari golongan bakteri asam laktat homofermentatif yang manpu melakukan fermentasi dalam keadaan aerob sampai anaerob. Asam laktat yang dihasilkan selama proses fermentasi akan berperan sebagai zat pengawet sehingga dapat menghindarkan pertumbuhan mikroorganisme pembusuk.

Proses pembuatan silase memanfaatkan bakteri asam laktat. Penambahan bahan starter yang mengandung gula pada pembuatan silase dapat membantu mempercepat dalam proses peningkatan kualitas silase. Terdapat beberapa starter yang dapat digunakan dalam pembuatan silase, di antaranya molases dan dedak padi. Bahan-bahan tersebut mengandung gula sederhana yang dapat membantu proses peningkatan kualitas silase. Kualitas silase dapat dipengaruhi oleh kualitas hijauan dan starter yang digunakan dan dapat dilihat dari kadar air, kadar protein kasar, dan kadar serat kasar pada silase.

Berdasarkan uraian yang telah dijelaskan tersebut, perlu dilakukan penelitian mengenai pengaruh perbedaan varietas dan starter terhadap kadar air, kadar protein kasar, dan kadar serat kasar silase tebon jagung.

\section{MATERI DAN METODE}

\section{Waktu dan Tempat Penelitian}

Penelitian ini dilaksanakan pada bulan Mei-Agustus 2019. Penanaman jagung dilakukan di lahan dekat perumahan, dengan luas lahan 24x8 $\mathrm{m}^{2}$. Penanaman jagung dan pembuatan silase dilakukan di Desa Rejo Binangun, Kecamatan Raman Utara, Kabupaten Lampung Timur dan analisis proksimat dilaksanakan di Laboratorium Nutrisi dan
Makanan Ternak, Jurusan Peternakan, Fakultas Pertanian, Universitas Lampung.

\section{Bahan dan Alat}

Bahan yang digunakan dalam penelitian hasil ensilase ini meliputi tebon jagung varietas Bisi-18 dan NK-212 dengan umur panen 60 hari, molases, dedak padi. Bahan yang digunakan dalam analisis proksimat antara lain $\mathrm{H}_{2} \mathrm{SO}_{4}$ pekat, air suling, $\mathrm{H}_{2} \mathrm{BO}_{3}$, indikator $\mathrm{NaOH} 45 \%$, $\mathrm{HCl} 0,1 \mathrm{~N}, \mathrm{H}_{2} \mathrm{SO}_{4} 0,25 \mathrm{~N}, \mathrm{NaOH} 0,313 \mathrm{~N}$, dan aseton.

Alat yang digunakan dalam penelitian ini antara lain plastik ukuran $10 \mathrm{~kg}$, tali plastik, baskom/ nampan, dan sarung tangan silikon. Alat yang digunakan untuk analisis proksimat adalah kertas saring, oven, tang penjepit, labu kjedahl, alat destruksi, erlenmeyer, gelas ukur, alat destilasi, alat titrasi, corong, botol semprot, desikator, tanur, cawan porselen, soxhlet, kondensor, timbangan analitik dan kompor listrik.

\section{Metode}

Penelitian ini menggunakan metode Rancangan Acak Lengkap (RAL) Faktorial 2x2. Perlakuan yang diberikan sebagai berikut. Tebon jagung varietas BISI-18 dengan penambahan molases $16,87 \%$ dari berat kering tebon jagung (V1M1), tebon jagung varietas BISI-18 dengan penambahan dedak padi $20,75 \%$ dari berat kering tebon jagung (V1M2), tebon jagung varietas NK-212 dengan penambahan molases $18,69 \%$ dari berat kering tebon jagung (V2M1), dan tebon jagung varietas NK-212 dengan penambahan dedak padi 22,99\% dari berat kering tebon jagung (V2M2). Penelitian ini menggunakan 4 kombi-nasi perlakuan dan 3 kali ulangan sehingga terdapat 12 unit percobaan. Jumlah bahan yang digunakan yakni hijauan tebon jagung sebanyak $84 \mathrm{~kg}$ berdasarkan berat layu. Masing-masing perlakuan dan ulangan menggunakan $7 \mathrm{~kg}$ bahan baku berdasarkan berat layu hijauan.

Kegiatan penelitian meliputi pembuatan silase tebon jagung dan tahap analisis proksimat yang meliputi kadar air, kadar protein kasar dan kadar serat kasar silase. Data yang diperoleh dari hasil pengamatan disajikan dalam bentuk tabel dan dianalisis secara statistik. Data yang diperoleh dianalisis dengan sidik ragam pada taraf nyata $5 \%$. Jika hasilnya berbeda nyata dilakukan uji lanjut Duncan untuk mengetahui perlakuan terbaik (Muhtarudin dkk., 2011). 


\section{HASIL DAN PEMBAHASAN}

\section{Pengaruh Perlakuan terhadap Kadar Air Silase Tebon Jagung}

Berdasarkan hasil analisis ragam menunjukkan bahwa tidak terjadi interaksi $(\mathrm{P}>0,05)$ antara perlakuan varietas jagung dan starter pada proses ensilasi terhadap kadar air silase tebon jagung. Dengan demikian, tidak ada perlakuan kombinasi terbaik terhadap kadar air silase tebon jagung. Hasil analisis ragam pada varietas tebon jagung yang berbeda menghasilkan kadar air yang tidak berbeda nyata $(\mathrm{P}>0,05)$. Hal ini diduga, karena kadar air pada kedua varietas tebon jagung sebelum ensilasi relatif sama (BISI-18 sebesar 78,41\% dan NK212 sebesar 80,84\%). Berdasarkan rata-rata kadar air silase tebon jagung menunjukkan bahwa kadar air silase tebon jagung varietas BISI-18 (72,09 $\pm 2,83 \%) \quad$ lebih rendah dibandingkan dengan silase tebon jagung varietas NK-212 $(73,17 \pm 2,57 \%)$. Hal tersebut sesuai dengan kondisi kadar air tebon jagung sebelum proses ensilasi pada varietas BISI-18 $(78,41 \%)$ juga lebih rendah dibandingkan varietas NK-212 (80,84\%). Rata-rata kadar air silase hasil percobaan ini dapat dilihat pada Tabel 1.

Tabel 1. Rata-rata kadar air silase tebon jagung

\begin{tabular}{cccc}
\hline Perlakuan & Molases & Dedak & Rata-rata \\
\hline & $-----------(\%$ berdasarkan BS $)-------------------$ & \\
BISI-18 & 73,03 & 71,14 & $72,09 \pm 2,83^{\text {tn }}$ \\
NK-212 & 74,89 & 71,44 & $73,17 \pm 2,57^{\text {tn }}$ \\
\hline Rata-rata & $73,96 \pm 2,57^{\text {tn }}$ & $71,29 \pm 1,60^{\text {tn }}$ & \\
\hline
\end{tabular}

Keterangan : $\mathrm{tn}=$ Tidak berbeda nyata $(\mathrm{P}>0,05)$ BS $=$ Berat Segar

Setiap hijauan yang berbeda akan menghasilkan respon yang mungkin berbeda pada proses pembuatan silase. Menurut pendapat Syahrir et al. (2014) kadar air bahan sebelum dan sesudah proses pembuatan silase yang berbeda disebabkan oleh adanya proses respirasi yang dapat mengurangi kadar air bahan atau terbentuknya air metabolisme pada saat proses fermentasi berlangsung yang dapat meningkatkan kadar air silase. Peningkatan kadar air setelah proses fermentasi kemungkinan disebabkan masih banyaknya udara pada silo sehingga terjadi proses respirasi aerob yang lebih lama.

Hasil penelitian ini menunjukkan adanya penurunan kadar air tebon jagung dari kondisi segar dan setelah mengalami proses ensilasi, penurunan kadar air tersebut kemungkinan disebabkan karena sedikitnya udara pada saat proses fermentasi sehingga menghasilkan air yang lebih sedikit pada saat respirasi berlangsung.

Berdasarkan hasil analisis ragam pada perlakuan starter berbeda menghasilkan kadar air silase tebon jagung yang tidak berbeda nyata $(\mathrm{P}>0,05)$. Hal ini menunjukkan bahwa molases dan dedak padi tidak mempengaruhi kadar air silase tebon jagung, namun berdasarkan rata-rata kadar air silase tebon jagung menunjukkan bahwa kadar air silase tebon jagung dengan starter molases $(73,96 \pm 2,57 \%)$ lebih tinggi dibandingkan kadar air silase tebon jagung dengan starter dedak padi $(71,29 \pm 1,60)$. Hal tersebut disebabkan oleh kontribusi kadar air molases $(27,18 \%)$ lebih tinggi daripada kadar air dedak padi $(10,42 \%)$ pada proses ensilasi.

Molases dan dedak padi tidak mempengaruhi kadar air silase tebon jagung, hal ini selaras dengan hasil penelitian Anas dan Syahrir (2017) pada pembuatan silase rumput mulato yang mendapatkan tambahan starter (dedak padi, molases, dan onggok) sebesar 5\% dari bahan kering dan menghasilkan kandungan bahan kering silase yang tidak berbeda nyata. Oleh karena itu, kandungan air pada silase tersebut juga tidak berbeda nyata. Hal ini memperkuat hasil pada penelitian ini bahwa molases dan dedak padi tidak mempengaruhi kadar air silase tebon jagung

\section{Pengaruh Perlakuan terhadap Kadar Protein Kasar Silase Tebon Jagung}

Berdasarkan hasil analisis ragam menunjukkan bahwa tidak terjadi interaksi $(\mathrm{P}>0,05)$ antara perlakuan varietas tebon jagung dan starter pada proses ensilasi terhadap kadar protein kasar silase tebon jagung. Dengan 
demikian tidak ada perlakuan kombinasi terbaik terhadap kadar protein kasar silase tebon jagung.
Rata-rata kandungan protein kasar silase hasil percobaan ini dapat dilihat pada Tabel 2.

Tabel 2. Rata-rata kadar protein kasar silase tebon jagung

\begin{tabular}{cccc}
\hline Perlakuan & Molases & Dedak & Rata-rata \\
\hline BISI 18 & 8,80 & 10,55 & $9,68 \pm 1,22^{\text {tn }}$ \\
NK 212 & 9,75 & 11,06 & $10,41 \pm 1,68^{\text {tn }}$ \\
\hline Rata-rata & $9,28 \pm 0,85^{\text {th }}$ & $10,81 \pm 1,58^{\text {tn }}$ &
\end{tabular}

Keterangan $:$ tn $=$ Tidak berbeda nyata $(\mathrm{P}>0,05)$

$\mathrm{BK}=$ Berat Kering

Hasil analisis ragam untuk perlakuan beda varietas menghasilkan kadar protein kasar silase tebon jagung yang tidak berbeda nyata $(\mathrm{P}>0,05)$. Hasil uji proksimat masing-masing bahan menunjukkan kadar protein kasar hijauan tebon jagung varietas BISI-18 sebesar 9,11\% dan kandungan protein kasar hijauan tebon jagung varietas NK-212 sebesar 10,00\%. Berdasarkan rata-rata kadar protein kasar silase tebon jagung menunjukkan bahwa kadar protein kasar silase tebon jagung varietas BISI-18 (9,68 $\pm 1,22 \%)$ lebih rendah dibandingkan dengan silase tebon jagung varietas NK-212 (10,41 $1,68 \%)$. Hal tersebut dipengaruhi oleh kadar protein kasar tebon jagung sebelum proses ensilasi pada varietas BISI-18 (9,11\%) lebih rendah dibandingkan varietas NK-212 (10,00\%). Kadar protein kasar kedua varietas setelah proses ensilasi menghasilkan protein kasar silase yang lebih tinggi daripada sebelum ensilasi, hal ini kemungkinan disebabkan oleh kandungan protein kasar starter yang ditambahkan pada proses ensilasi.

Sulaeman et al., (2014) menyatakan bahwa pada prinsipnya silase tidak meningkatkan kandungan nutrisi pakan, tetapi dapat mempertahankan nutrisi. Kandungan karbohidrat yang tinggi pada molases dan dedak menyebabkan bakteri asam laktat berkembang lebih baik. Karbohidrat sederhana pada starter tersebut dapat meningkatkan perkembangan bakteri asam laktat, sehingga $\mathrm{pH}$ turun dan bakteri pembusuk tidak dapat tumbuh. Kondisi tersebut dapat mencegah terurainya protein selama penyimpanan. Hal ini didukung oleh pendapat Nishino et al., (2003) yang menyatakan bahwa peningkatan karbohidrat terlarut air dalam pembuatan silase dapat menurunkan kehilangan bahan kering dan protein kasar selama ensilasi.
Penelitian yang dilakukan Sanjaya et al. (2019) menunjukkan bahwa kadar protein kasar silase hijauan sorghum lebih tinggi (7,45\%) dibandingkan silase tebon jagung $(7,08 \%)$ yang disebabkan kandungan protein kasar hijauan sorghum sebelum menjadi silase lebih tinggi dibandingkan tebon jagung. Hasil tersebut memperkuat bahwa kandungan nutrisi bahan mempengaruhi kandungan nutrisi silase.

Berdasarkan hasil analisis ragam dapat diketahui perbedaan starter menghasilkan kadar protein kasar silase tebon jagung yang tidak berbeda nyata $(\mathrm{P}>0,05)$. Hal ini menunjukkan bahwa molases dan dedak padi sebagai starter ensilasi tidak mempengaruhi kadar protein kasar silase tebon jagung, namun pada tabel rata-rata kadar protein kasar silase tebon jagung (Tabel 5) menunjukkan bahwa silase tebon jagung dengan menggunakan starter dedak padi memiliki kadar protein kasar $(10,81 \pm 1,58 \%)$ lebih tinggi dibandingkan menggunakan starter molases $(9,28 \pm 0,85 \%)$, karena kadar protein kasar dedak padi $(11,00 \%)$ lebih tinggi dibandingkan molases (3,27\%). Hasil tersebut selaras dengan hasil penelitian yang dilakukan Anas dan Syahrir (2017) pada pembuatan silase rumput mulato yang masing-masing perlakuannya diberi starter berbeda yaitu dedak padi, molases, dan onggok, menghasilkan kandungan protein kasar tertinggi pada silase rumput mulato yang menggunakan starter dedak padi sebesar $11,20 \%$.

\section{Pengaruh Perlakuan terhadap Kadar Serat Kasar Silase Tebon Jagung}

Perlakuan vareitas tebon jagung yang berbeda dan starter yang berbeda berdasarkan hasil analisis ragam menunjukkan bahwa tidak 
terdapat interaksi $(\mathrm{P}>0,05)$ antara penggunaan jenis varietas tebon jagung dan starter pada kadar serat kasar silase tebon jagung. Dengan demikian tidak ada perlakuan kombinasi terbaik terhadap kadar serat kasar silase tebon jagung. Rata-rata kandungan serat kasar silase hasil percobaan ini dapat dilihat pada Tabel 3.

Tabel 3. Rata-rata kadar serat kasar silase tebon jagung

\begin{tabular}{cccc}
\hline \multirow{2}{*}{ Perlakuan } & Molases & Dedak & Rata-rata \\
\hline & 28,26 & 29,05 & $28,65 \pm 2,05^{\text {tn }}$ \\
BISI 18 & 28,49 & 29,82 & $29,16 \pm 2,28^{\text {tn }}$ \\
NK 212 & $28,38 \pm 1,90^{\text {tn }}$ & $29,44 \pm 2,14^{\text {tn }}$ & \\
\hline Rata-rata &
\end{tabular}

Keterangan $:$ tn $=$ Tidak berbeda nyata $(\mathrm{P}>0,05)$ $\mathrm{BK}=$ Berat Kering

Hasil analisis ragam pada perlakuan beda varietas menghasilkan kadar serat kasar silase tebon jagung yang tidak berbeda nyata $(\mathrm{P}>0,05)$. Hal ini diduga karena kandungan serat kasar pada kedua varietas tebon jagung sebelum proses ensilasi tidak jauh berbeda. Hasil uji proksimat masing-masing bahan menunjukkan kadar serat kasar hijauan tebon jagung varietas BISI-18 sebesar 29,27\% dan kadar serat kasar hijauan tebon jagung varietas NK-212 sebesar 31,03\%. Berdasarkan rata-rata kadar serat kasar silase tebon jagung menunjukkan bahwa kadar serat kasar silase tebon jagung varietas BISI-18 $(28,65 \pm 2,05 \%)$ lebih rendah dibandingkan dengan silase tebon jagung varietas NK-212 $(29,16 \pm 2,28 \%)$. Hal tersebut dipengaruhi oleh kadar serat kasar tebon jagung sebelum proses ensilasi pada varietas BISI-18 (29,27\%) lebih rendah dibandingkan varietas NK-212 (31,03\%). Berdasarkan hasil analisis ragam diketahui perlakuan starter berbeda menghasilkan kadar serat silase tebon jagung yang tidak berbeda nyata $(\mathrm{P}>0,05)$. Hal ini menunjukkan bahwa molases dan dedak padi tidak mempengaruhi kadar serat kasar silase tebon jagung, namun pada tabel rata-rata kadar serat kasar silase tebon jagung menunjukkan bahwa kadar serat kasar silase tebon jagung dengan starter molases $(28,38 \pm 1,90 \%)$ lebih rendah dibanding silase tebon jagung dengan starter dedak padi $(29,44 \pm 2,14 \%)$. Hal ini diduga disebabkan kandungan serat kasar molases $(0,89 \%)$ lebih rendah dibandingkan dengan dedak padi $(10,72 \%)$ sehingga silase dengan tambahan starter molases memiliki kandungan serat kasar lebih rendah dibandingkan dengan starter dedak padi.
Hasil penelitian ini selaras dengan penelitian yang dilakukan Anas dan Syahrir (2017) yang melaporkan bahwa kadar serat kasar silase rumput mulato dengan starter berupa molases memiliki kadar serat kasar (22,79\%) lebih rendah dibanding silase dengan starter dedak padi (24,28\%). Hasil penelitian Sanjaya et al. (2019) juga melaporkan bahwa kadar serat kasar silase tebon jagung dan sorghum dengan starter molases $(30,69 \%)$ lebih rendah dibandingkan dengan starter dedak padi (33,24\%).

Sanjaya et al. (2019) menyatakan rendahnya kandungan serat kasar pada perlakuan penambahan starter silase disebabkan oleh tingginya aktivitas bakteri selulitik selama fermentasi. Mikroorganisme yang terdapat dalam proses fermentasi mendegradasi selulosa dan hemiselulosa sehingga serat kasar hijauan dapat menurun setelah proses ensilase. Pernyataan tersebut didukung dengan pendapat Kalsum dan Sjofjan (2008)yang menyatakan mikroba akan mendegradasi bahan organik seperti gula, protein, pati, hemiselulosa dan selulosa untuk pertumbuhannya. Walaupun demikian, hasil penelitian ini, dengan perlakuan starter molases dan dedak padi tidak berpengaruh terhadap kadar serat kasar silase tebon jagung.

\section{SIMPULAN DAN SARAN}

\section{Simpulan \\ Berdasarkan penelitian yang telah dilakukan dapat disimpulkan bahwa:}


1. tidak ada interaksi antara varietas dan starter pada silase tebon jagung terhadap kadar air, kadar protein kasar, dan kadar serat kasar silase

2. tidak ada perlakuan kombinasi terbaik terhadap kadar air, kadar protein kasar, dan kadar serat kasar silase tebon jagung.

3. tidak ada pengaruh varietas jagung terhadap kadar air, kadar serat kasar, dan kadar serat kasar silase tebon jagung dan tidak ada pengaruh starter terhadap kadar air, kadar protein kasar, dan kadar serat kasar silase tebon jagung.

\section{Saran}

Saran yang dianjurkan penulis berdasarkan penelitian ini adalah perlu dilakukan penelitian lanjutan dengan varietas dan starter yang lebih bervariasi.

\section{DAFTAR PUSTAKA}

Anas M. R., dan Syahrir. 2017. Pengaruh Penggunaan Jenis Aditif sebagai Sumber Karbohidrat terhadap Komposisi Kimia Silase Rumput Mulato. Jurnal Agrisains 18 (1) : $13-22$.

Fitri. 2015. Keunggulan Tebon Jagung Sebagai Hijauan Pakan Ternak Berkualitas dan Disukai Ternak. http://www.agrobisnisinfo.com/2015/07/ke unggulan-tebon-jagung-sebagai-hijauan.

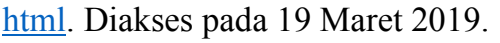

Kalsum, U dan O. Sjofjan. 2008. Pengaruh waktu inkubasi campuran ampas tahu dan onggok yang difermentasi dengan Neurosporasitophila terhadap kandungan zat makanan. Prosiding Seminar Nasional Teknologi Peternakan dan Veteriner Bogor. Puslitbang Peternakan, Bogor. 226-232.

Muhtarudin, Erwanto, dan A. Dakhlan. 2011. Teknik Penelitian untuk Ilmu Peternakan. Aura. Bandar Lampung.

Nishino, N., H. Harada., and E. Sakaguchi. 2003. Evaluation of fermentation and aerobic stability of wet brewers' grains ensiled alone or in combination with various feeds as a total mixed ration. Journal. Science Food. Agriculture. 883: 557-563.

Sanjaya H. B. 2019. Perbandingan Kualitas Nutrisi Silase Tebon Jagung dan Sorghum yang diberi Bahan Aditif Berbeda. Fakultas
Pertanian. Universitas Lampung. Bandar Lampung.

Subekti. G., Suwarno, dan N. Hidayat. 2013. Penggunaan beberapa aditif dan bakteri asam laktat terhadap karakteristik fisik silase rumput gajah pada hari ke- 14 . Jurnal Ilmiah Peternakan 1 (3): 835-841.

Sulaeman. E., D.S. Tasripin dan U.H. Tanuwiria. 2014. Prinsip Silase. Jurnal. Universitas Padjadjaran. Bandung. Vol 2 No. 8: 55-56.

Syahrir S., S. Rasjid, M. Z. Mide dan Harfiah. 2014. Perubahan terhadap Kadar Air, Berat Segar dan Berat Kering Silase Pakan Lengkap Berbahan Dasar Jerami Padi dan Biomassa Murbei. Buletin Nutrisi dan Makanan Ternak, Vol 10. 